\title{
EMPLOYEE WELLBEING AND ORGANIZATIONAL EFFECTIVENESS OF OIL AND GAS FIRMS IN RIVERS STATE, NIGERIA
}

\author{
OMOANKHANLEN JOSEPH AKHIGBE \\ Department of Management, University of Port Harcourt, \\ Port Harcourt, Nigeria \\ https://doi.org/10.37602/IJSSMR.2021.4209
}

\begin{abstract}
This study deals with the nexus amongst employee wellbeing and organizational effectiveness of oil and gas firms in Rivers State, Nigeria. The cross-sectional survey was adopted. A total population of six hundred and sixty-five (665) employees from 10 oil and gas firms in Rivers State, Nigeria, was covered in this work. A sample size of 250 was drawn from the population. The simple random sampling technique was employed. The questionnaire was used to obtain the necessary data from respondents. The spearman rankorder correlation was used for analysing the data. The result revealed that the dimensions of employee wellbeing (job satisfaction, and work-life balance satisfaction) had a significant positive relationship with cohesion and productivity. It was thus concluded that enhancing the total wellbeing of the employees by ensuring job satisfaction and work-life balance satisfaction of the employees, will help enhance the total effectiveness of the organization. Hence, the study recommended that organizations should ensure that staffs are well rewarded so as to boost their job satisfaction in the workplace and thus improve the firm's effectiveness.
\end{abstract}

Keywords: Cohesion, Employee Wellbeing, Job Satisfaction, Organizational Effectiveness, Productivity, Work-Life Balance Satisfaction.

\subsection{INTRODUCTION}

Organizations as a goal-seeking entity, are constantly in search of the best ways to improve their effectiveness in the industry. The effectiveness of an organization is critical and relevant in ensuring that the firm is able to realise its goals and remain agile in an ever-changing business environment. The business domain is highly characterized by high imponderable varieties and only organizations that are effective will be able to withstand the harsh nature of the environment. As such, effectiveness has become a concern of management in recent times. The effectiveness of a corporation is important because of its indisputable role in heightening the competitive ability of any establishment. Oghojafor, Muo and Adulojo (2012) maintained that effectiveness depicts the ultimate and measure of organizational and managerial performance. 


\section{International Journal of Social Sciences and Management Review}

Volume: 04, Issue: 02 "March - April 2021"

ISSN 2582-0176

The effectiveness of corporations is the extent to which a firm as a social entity, achieve its goals with certain means and resources without posing undue strain upon its members or incapacitating its resources (Georgopoulos \& Tannenbaum, 2016). According to Oghojafor, Muo and Aduloju (2012), effectiveness is the accomplishment of a firm purpose which is often social and non-personal in character. They argued that organizations are bound to fizzle out of business when there is ineffectiveness. In alignment with the assertion above, organizational effectiveness can thus be seen as a glue that helps sustain the continuity of a firm even in a highly proliferating environment. Organizational effectiveness is the firm's proficiency at accessing its essential resources. Organizational effectiveness is further relevant to organizations because it helps enhance their profitability, boost their market share, increase the competitiveness in the industry and help enhance the survival of the organization even in a hostile environment. In an attempt to measure organizational effectiveness, several measures have been propounded by various schools over the years.

According to Carton (2004), the measures of organizational effectiveness include adaptability, productivity, absence of strain, satisfaction, efficiency, profitability, growth and survival. Martz (2008) identified productivity, efficiency, stability, innovation, growth, output quality and cohesion as the measures of organizational effectiveness. Agbionu, Ogagi and Agbasi (2013) opined that effectiveness is geared towards successful achievement of the organizational mission through their core strategies.

It is worthwhile to contend here that the achievement of effectiveness does not totally depend on the sophisticated equipment of the firm but on the employees that pilot the affairs of the corporations. Thus, it is paramount that organizations pay high attention to enhancing the wellbeing of its staffs as such could influence their performance and attitude in the workplace and as such boost the total effectiveness of the firm. Employee wellbeing is a key indicator for enhancing organizational success, (Krishantha, 2018). Employee wellbeing has been a vital tool for enhancing the performance and survival of firms (Agbionu, Ogagi \& Agbasi, 2013), reducing turnover and absenteeism and promoting a healthy workforce (Cooper \& Robertson, 2001). Employee wellbeing at work is the physical and mental health of the workforce. Employee wellbeing refers to the entire facet of the working life of an employee, from the superiority and security of the environment of work, to how staffs feel in their job. Baptiste (2008) identified job satisfaction, employee commitment, supervisory support and work-life balance satisfaction as the dimensions of employee wellbeing. The wellbeing of an employee has an impact on his/her psychological state which therefore influence their positive attitude in the workplace.

Over the years, several inquiries have invested in ways of enhancing a corporation's effectiveness. Olaniyan and Ojo (2008) examined how training and the development of staffs relate to organizational effectiveness. Agbiondu, Ogadi and Agbasi (2013) examined how job satisfaction relates to the organizational effectiveness of public organizations in Anambra State. Amah and Ahiauzu (2013) examined how employee involvement relates to the effectiveness of banks in Nigeria. They maintained that an increase in employee involvement will boost the effectiveness of corporations. However, despite the several scholarly works on how to enhance organizational effectiveness, there is scanty empirical work on employee wellbeing and effectiveness of oil and gas firm. It is this observed gap that has informed this study. 


\section{International Journal of Social Sciences and Management Review}

Volume: 04, Issue: 02 "March - April 2021"

ISSN 2582-0176

\section{Statement of the Problem}

The effectiveness of firms is of high importance to the firm and to the economic wellbeing. The effectiveness of the oil and gas firm has been negatively affected due to the high turbulence in the business environment coupled with unfavourable internal and external influence. The contribution of this sector to the Gross Domestic Product (GDP) of the country has reduced drastically in the past few years. The ineffectiveness of this sector has affected several firms depending on the sector and thus has negatively affected the wellbeing of the country. The issue of ineffectiveness in the oil and gas firms has over time lead to the retrenchment of some employees and a low level of competitiveness. The oil and gas firms operating in a highly volatile environment and a low level of ineffectiveness may result in the high mortality rate of the firm.

Furthermore, the problem of ineffectiveness of the oil and gas firms has manifested in a low balance of trade in the country, it has intensified poor economic activities which has resulted to intensive poverty and hunger in the country. A low level of effectiveness has also resulted in low market share, low adaptive and resilience capability. Furthermore, the low poor effectiveness over the years has also lead to reducing the profitability of firms which if not addressed urgently may result in the liquidation of the firm. Organizational image and survival are upshot of the degree of the effectiveness of the corporate. As such ineffectiveness results in dwindling growth which affects the survival of firms. Ogbo, Okechukwu and Ukpere (2012) observed that the ineffectiveness of firms results in discontentment of employees, absence of commitment and sabotage. Despite the various work by previous scholars to address the issue of ineffectiveness, the problem still persists. Workers who are the main resources of the establishment possess the ability to boost the total effectiveness of any organization. Thus, employee wellbeing could thus be relevant in enhancing the effectiveness of the firm. It is on this note that this study critically examined how employee wellbeing can help enhance the effectiveness of oil and gas firms in Rivers State, Nigeria.

\section{Research Objectives}

The objectives of this study are to examine the relationship between;

I. Job satisfaction and cohesion.

II. Job satisfaction and productivity.

III. Work-life balance satisfaction and cohesion.

IV. Work-life balance satisfaction and productivity.

\section{Research Questions}

The following research questions served as a guild in this study;

I. How does Job satisfaction relate to cohesion?

II. How does job satisfaction relate to productivity?

III. How does work-life balance satisfaction relate to cohesion?

IV. How does work-life balance satisfaction relate to productivity? 


\section{International Journal of Social Sciences and Management Review}

Volume: 04, Issue: 02 "March - April 2021"

ISSN 2582-0176

\section{Research Hypotheses}

The following research hypotheses served as a tentative answer to the research questions;

HO1: There is no significant relationship between job satisfaction and cohesion of oil and gas firms in Rivers State, Nigeria.

HO2: There is no significant relationship between job satisfaction and productivity of oil and gas firms in Rivers State, Nigeria.

HO3: There is no significant relationship between work-life balance satisfaction and cohesion of oil and gas firms in Rivers State, Nigeria.

HO4: There is no significant relationship between work-life balance satisfaction and productivity of oil and gas firms in Rivers State, Nigeria.

\subsection{LITERATURE REVIEW}

This work is founded on the happy/productive worker theory. Many researchers analyze what influences employee wellbeing because they wanted to find out how to increase organization performance or productivity by promoting employee happiness effectively (Russell, 2008). Cropanzano and Wright (2001) detected that un-happy individuals are easily influenced by work and position changes and cannot cooperate with co-workers effectively. Happy employees can have an effect on a firm's bottom line and create a workplace where worker's and individual look onward to relate with each other (Nandanwar, Surnis \& Nandanwar, 2010). This is founded on the postulation that when workers need is well gratified, such will make them happy and thus more productive. Herzberg, Mausner and Snyderman (1959) stated that (positive) fulfilment is due to outstanding experiences and that happiness is due to "motivators" - realization of duties, duly recognized, the work itself, responsibility and promotion. If staffs are inspired and happy they will do their work to the best of their ability rather than doing it because of its necessity (Ryan, \& Deci, 2000). This theory is relevant to this work because when employees wellbeing is taken into consideration by the organization, such leads to the happiness of the staffs which thus influences the positive approach to work and hence boost the effectiveness of the corporations.

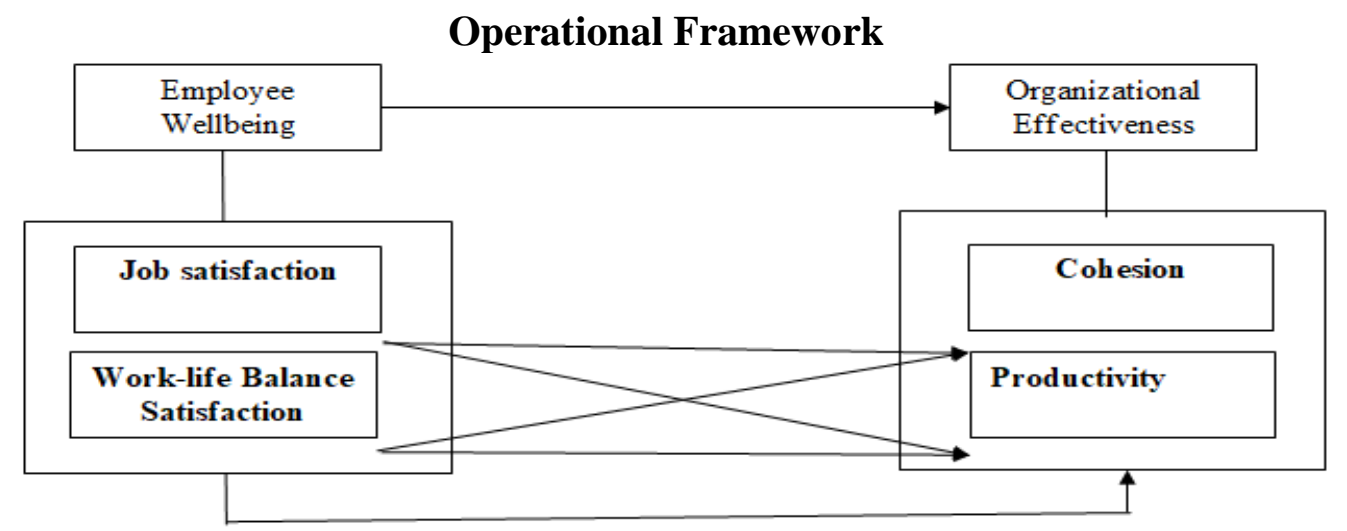




\section{International Journal of Social Sciences and Management Review}

Volume: 04, Issue: 02 "March - April 2021"

ISSN 2582-0176

Figure: Conceptual framework.

Source: Adapted from Baptiste (2008); Carton (2004) and Martz (2008).

\section{Concept of Employee Wellbeing (EWB)}

Organizations are universally becoming more enlightened of issues linked with staff's wellness or well-being (Hooper, 2004) and Hillier, Fewell, Cann and Shephard (2005) posited that there is an improved interest in getting wellness activities into the system. Employee wellbeing has to do with Generating a work domain to promote a condition of serenity and contentment which permits employees to flourish and accomplish their optimum potential to benefit the firm and themselves (CIPD, 2007). Boosting well-being consequently has all the necessary potential to motivate staffs to work diligently and smarter (Oswald, Proto \& Sgroi, 2014). Employee wellbeing (EWB) also has a straight forward effect because individuals with higher EWB are most likely to partake in health-promoting attitudes and practices (Grant, Wardle \& Steptoe, 2009). Serxner (2001) also discovered that people who join in the wellness programs had a lesser absenteeism ratio compared to individuals who did not join in the wellness programs. Corbin, et. al. (2002) explained wellness as an individual's state of welfare that results in a better quality of life. Parks and Steelman (2008) in their extent of studies discovered that employees who partake in organizational wellness programs were connected to fewer stress levels, lesser absenteeism, improved job gratification and production increases. Currie (2001) pointed out his definition of employee well-being which is the moment of happiness, body and psychological health of workers. The rationale behind the introduction of the EWB programme in firms is to establish an advertisement of wellness issues, to carry up the personal change, and to encourage a healthy and helpful work domain (Anonymous, 2007). Employee wellbeing (EWB) is primarily an effective or emotional experience.

\section{Job Satisfaction (JS)}

Job satisfaction (JS) is a concept that influences employees psychological well-being in the organization. Hoppock (1935) explained job satisfaction to imply a combination of emotional, substantial and surrounding circumstances that stir an individual to indicate their gratification with the job. Locke (1976) explains job satisfaction to be an enjoyable or good emotional state gotten from the valuation of an individual's job or experiences. HRM is a concentrated functional section of business that moves to create some "programs, policies, and activities" to motivate the job gratification of both staffs and organizational basic objectives (Armstrong, 1987). Vroom (1964) explains job satisfaction as the affective orientation of staffs towards job duties that they are currently handling. Workers who have greater job gratification are unlikely going to miss a day off, would not want to leave, increases productivity and most likely to display commitment in his company (Lease, 1998). Satisfaction is mostly considered as a propeller of workers retention and staff's productivity (Salanova \& Kirmanen, 2010). Ellickson and Logsdon (2002) support this view by stating that satisfaction depicts the level of gratification of workers in their jobs. Bad influence and unfavourable emotions towards the work indicate dissatisfaction on the job (Armstrong, 2006). Ndulue and Ekechukwu (2016) maintained that employee satisfaction relates positively to cohesion. Schermerhorn, Hunt and Osborn (2003) contended that satisfaction is an "affective or emotional response" which occurs in various sections of an individual's 


\section{International Journal of Social Sciences and Management Review}

Volume: 04, Issue: 02 "March - April 2021"

ISSN 2582-0176

work. Individuals also can have emotions about separate aspects of their assignments such as the kind of occupation they do, their colleagues, and their compensation (George \& Jones, 2008). JS is complex with multi appearances and influence by the determinants like compensation, job surroundings, freedom, and commitment (Vidal, Valle \& Aragón, 2007).

\section{Work-Life Balance Satisfaction (WLBS)}

Work-life balance satisfaction (WLBS) is very imperative to any organizations and individuals to obtain top-notch management of various tasks at the place of work, place of rest, and personal life, as workers/individuals with high work-life balance tends to contribute more towards organizational growth and success (Naithani, 2010). Work-life balance is specifically essential when companies have to organize and control vastly technical professional, owing to that their dedication and allegiance is required for the progress of the establishment (Scholarios \& Marks, 2006). According to Singh (2013), there is a keen observation in work-life connection in psychology, mainly in the materials and output of disagreements between work-to-life and life-to-work spheres in recent times. Individuals/worker's WLBS and their commitment play a paramount role in the performance and productivity of corporations (Sakthivel \& Kamalanabhan, 2011; Sakthivel \& Jayakrishnan, 2012). WLBS is not only about families and childcare, but also about working less.

Work-life balance denotes the balance of materials and problems between the place of work and house domain as in a family or other personal roles (Frone, 2003; Quick, Henley, \& Quick, 2004). Work-life balance term is explained as the range of timing a worker spends on both at his/her job compared with time spent with family, friends and going for other interest personally (Smith, 2010). From a company's point of understanding, work-life balance may be a section of good work outcomes, and from a worker's point of understanding, it can be a good and encouraging factor in deciding to work for the company or stick with a particular company (Mayerhofer, Schmidt, Hartmann \& Bendl, 2011). WLBS denotes the ability to maintain equilibrium between private and work life (Szücs et al. 2011). Kossek and Lambert (2005) explained work-life benefits as the directed support laws and procedures provided by organizations in helping workers realize a better work-life. Nwagbara and Akanji (2012) described it as when any person's life obviously separates into two observed spheres: "work and life", with the former frequently having negative limitations on the latter. It deals with a daily routine to carve out time for family, friends, community participation, spirituality, personal growth, self-care and other personal activities" (Hasan et al., 2015). Good WLBS is a vital ingredient for organizations' success because it leads to larger productivity (Bloom, Krestschmer, \& Van, 2006). Nwogu and Kaegon (2013) explained work-life balance as the creation of opportunities for individuals to balance actual work conditions with the responsibilities and interests which the individuals hold for themselves outside the work schedule. From an organizational point of view, work-life balance can be a part of a good outcome, and from workers perspective, it may be a positive factor in deciding to work for or continue with a specific organization (Mayerhofer et al., 2011).

\section{Organizational Effectiveness (OE)}




\section{International Journal of Social Sciences and Management Review}

Volume: 04, Issue: 02 "March - April 2021"

ISSN 2582-0176

Effectiveness is a goal that all firms wish to achieve in all their operations so as to withstand any unforeseen variations in the environment. Organizational effectiveness is seen as the capability of firms, in either relative or absolute terms, to exploit their domain to acquire valued and scarce resources (Yuchtman \& Seashore, 1967). According to Daft (1983) Organizational structure plays an active role in determining the effectiveness of any organization, and the way organizational structure do practice are context-specific (Zheng, Yang, \& McLean, 2010). OE was succinctly seen in Daft (1983) as the extent to which an organization realized its goals. Shiva and Suar (2010) came to a conclusion that the effectiveness of higher-order is possible by transforming workers' attitudes towards the company from a lesser level to a higher stage. To boost OE, management need to strive for better communication, leadership, adaptability, interaction, direction and a positive environment. According to Campbell (1977), the various ways of understanding organizations has led to two main floods of thought in organizational effectiveness, namely goal-centred and natural systems approaches. The effectiveness of corporations is critical in enhancing the fortune of the organization.

\section{Cohesiveness}

Cohesiveness increases output when the work requires interaction owing that it is socially motivated and a source of social satisfaction (Argyle, 1989). The kind of bond in an establishment shows the extent of communication and understanding among the team associates (Rosh, Offermann, \& Van, 2012; Shaw, 1981). Cohesion is an influential procedure that is highlighted in the predisposition of a team to stay united. Carron, Brawley and Widmeyer (1998) Cohesion depicts an extensive and dynamic procedure that is mirrored in the propensity for a certain group to bond, stick together and stay united in the quest of its goals and established objectives. Group cohesiveness encircles a sense of belonging, attachment, harmony, and an attraction of a team for its members (Evans \& Dion, 1991). Argyle (1989) stated that cohesiveness probably affects output most when helping is important.

\section{Productivity}

Fundamentally, productivity denotes the ratio which determines how well a firm translates input resources into output which could either be services or goods (Yadav \& Marwah, 2015). Yadav \& Marwah, (2015) stated that Productivity denotes an index that measures firms output in relation to the input (labor, materials, energy, etc.). More precisely, productivity denotes how given resource is managed to realise timely goals as desired in terms of quality and quantity (Yadav \& Marwah, 2015). It is the capability of using resources gotten naturally to produce goods and services within the economy (Bleischwitz 2010). Productivity is useful as a relative measure of the actual output of production compared to the actual input of resources, measured across time or against common entities (Yadav \& Marwah, 2015). A better-utilized instrument with a hardened commitment and working on safe jobs also make contributions towards affecting labour productivity (Wiredu, 1989). Productivity has been generally explained to be a ratio of a benchmark of some or all of the materials used to manufacture an output.

\section{Empirical Review}




\section{International Journal of Social Sciences and Management Review}

Volume: 04, Issue: 02 "March - April 2021"

ISSN 2582-0176

The subject of effectiveness has been empirically examined by scholars. Agbionu, Ogadi and Agbasi (2013) examined how job satisfaction relates to firms effectiveness in public organizations in Anambra State. The work adopted a survey design questionnaire that was used in collecting data from different respondents. From a total of 139 questionnaires that were administered only 115 was successfully retrieved. The content, face and construct validity were used. The test-re-test reliability of 0.92 was obtained. The stated hypothesis was analyzed using the Spearman rank-order correlation. The result revealed that job satisfaction has a significant correlation with productivity and profitability which were the measures of organizational effectiveness. The study concluded that job satisfaction highly increases productivity and slightly boost profitability. Krekel, Ward and DeNeve (2019) did a workshop where they enquired into how employee wellbeing relates to productivity and performance. The study observed that employee satisfaction correlates positively with productivity. It was observed that employee satisfaction positively correlates with productivity and profitability with a correlational value of 0.20 and 0.16 respectively.

Sinikka and Kaija (2006) examined how employee wellbeing relates to company performance in the metal industry and retail trade in Finland. The research covered a period of 1998 to 2000. 235 firms were covered in 1997, 2599 employees from the different firm were covered in 1998 and 1389 employees from 91 firm was covered in the year 2000. A correlational analysis was carried out in the study. The findings revealed that employee wellbeing has a significant weak relationship with firm performance.

Ahmed and Shaheen (2011) did a critical study on how employee commitment impact the organizational performance of both private and public sector in Lahore, Rewalpindi and Islamabad region in Pakistan. A total sample size of 525 respondents was covered in the study. However, only 515 employees questionnaire was retrieved that employee commitment have a strong positive correlation with organizational performance. Thus, increasing commitment of employees will help enhance the performance and wellbeing of the firm. Irefin and Mechanic (2014) examined how employee commitment relates with organizational performance. Descriptive and explanatory research method was adopted. Data was collected through questionnaire. A total population of 120 employees from coca cola company in Borno State was covered. Hypothesis were tested using pearson correlation coefficient. The result of the study revealed that employee commitment have a high correlation of 0.782 with organizational performance. Yamamoto and Matsuura (2012) inquired into work-life balance practices on productivity corporations in Japanese firm. 9628 firms were covered, questionnaire were utilized in collecting data. However, only 1677 firms participated in the study. A correlational analysis was done and result showed that work life balance relates positively with firm productivity.

Garg and Yajurvedi (2016) examined how the practice of work-life balance relates with retention and performance of corporations in IT industry in Noida region. A survey method was employed. Data were gathered using interviews and questionnaire. The convenient sampling was utilized. The findings revealed that work-life balance relates significantly and positive with productivity. It was also observed that high quality of work life balance will help enhance job satisfaction.

\subsection{METHODOLOGY}




\section{International Journal of Social Sciences and Management Review}

Volume: 04, Issue: 02 "March - April 2021"

ISSN 2582-0176

This study used the cross sectional survey which is a type of quasi experimental design. The population comprises of the forty-five (45) oil and gas firms in Nigeria registered with the Department of Petroleum Resources. However, the accessible population are 665 managers and supervisors of 10 oil and gas firms in Rivers state. The Yamene (1968) formula was used to derive a sample size of 250. A structured questionnaire were personally administered to respondent. The simple random sampling technique was used on each of the ten selected companies. Employee wellbeing which is the independent variables was operationalized in job satisfaction and work-life balance satisfaction as given in Baptiste (2007). 5 items were used in measuring job satisfaction (e.g. I am gratified with the feeling of achievement I get from my job), 5 items were used in measuring work-life balance satisfaction (e.g. Flexible working options are available to me if needed). Organizational effectiveness was operationalized in cohesion and productivity as given in Carton (2004) and Martz (2008). 5 items were used in measuring cohesion (e.g. I feel a sense of cohesion with my co-workers in this organization), and 5 items were used in measuring productivity (e.g. We maximize the use of our raw material resources, and with a minimum of waste). The response to these items was measured on a 4 point likert, scales ranging from $1-4$. Where $1=$ Strongly disagree, $2=$ Disagree 3 = Agree and $4=$ Strongly agree. The Spearman Rank Order Correlation Coefficient statistical analysis was employed in analyzing the hypothesis in order to ascertain the relationship between the variables through the use of Statistical Package for Social Sciences (SPSS) version 21.

\subsection{RESULTS AND DISCUSSION}

A total of 250 copies of questionnaire were administered to respondents which was made up of managers and supervisors from ten (10) Oil and Gas firms in Rivers state. however, 188 copies of questionnaire which represented $75 \%$ of total distributed were retrieved and utilized for the study.

The decision rule is:

$\mathrm{p}<0.05$ significant level $=$ reject the null hypotheses

p> 0.05 significant level $=$ and accept the null hypotheses where .

All nine bivariate hypotheses were tested in the null form.

Table 1 Job Satisfaction and Measures of Organizational Effectiveness

\begin{tabular}{|c|c|c|c|c|c|}
\hline & & & Job Satisfaction & Cohesion & Productivity \\
\hline \multirow{9}{*}{ Spearman's rho } & & Correlation Coefficient & 1.000 & .159 & .162 \\
\hline & Job Satisfaction & Sig. (2-tailed) & & .009 & .007 \\
\hline & & $\mathrm{N}$ & 188 & 188 & 188 \\
\hline & & Correlation Coefficient & .159 & 1.000 & .006 \\
\hline & & Sig. (2-tailed) & .009 & & .937 \\
\hline & \multirow[t]{3}{*}{ Cohesion } & $\mathrm{N}$ & 188 & 188 & 188 \\
\hline & & Sig. (2-tailed) & .006 & .559 & .000 \\
\hline & & $\mathrm{N}$ & 188 & 188 & 188 \\
\hline & Productivity & Correlation Coefficient & .162 & .006 & 1.000 \\
\hline
\end{tabular}




\section{International Journal of Social Sciences and Management Review}

Volume: 04, Issue: 02 "March - April 2021”

ISSN 2582-0176

\begin{tabular}{|l|r|r|r|}
\hline Sig. (2-tailed) & .007 & .937 & 188 \\
$\mathrm{~N}$ & 188 & 188 & 188 \\
\hline
\end{tabular}

Ho1: There is no significant relationship between Job Satisfaction and the Cohesion of oil and gas firms in Rivers State.

The result of the analysis in Table 1 shows a significant level $\mathrm{p}<0.05(0.009<0.05)$, rho $=$ 0.159 between Job Satisfaction and Cohesion. The null hypothesis was rejected and the alternate accepted.

Ho2: There is no significant relationship between Job Satisfaction and Productivity of oil and gas firms in Rivers State.

The result of the analysis in Table 1 shows a significant level $\mathrm{p}<0.05(0.007<0.05)$, rho $=$ 0.162 between Job Satisfaction and Productivity. The null hypothesis was rejected, and the alternate was accepted.

Table 2 Work-Life Balance Satisfaction and Measures of Organizational Effectiveness

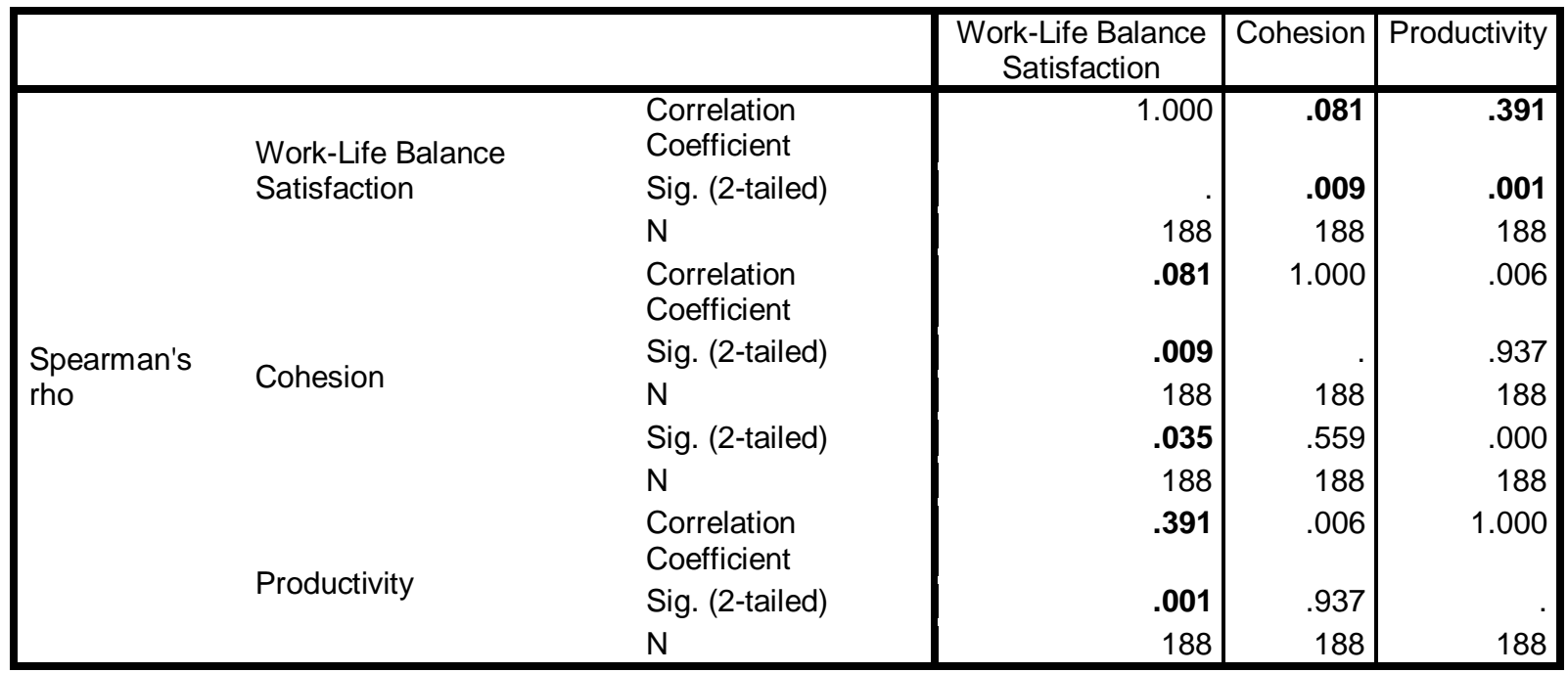

Ho3: There is no significant relationship between Work-Life Balance Satisfaction and Cohesion of oil and gas firms in Rivers State.

The result of the analysis in Table 2 shows a significant level $\mathrm{p}<0.05(0.009<0.05)$, rho $=$ 0.081 between Work-Life Balance Satisfaction and Cohesion. The null hypothesis was rejected and the alternate hypothesis was accepted.

Ho4: There is no significant relationship between Work-Life Balance Satisfaction and Productivity of oil and gas firms in Rivers State. 


\section{International Journal of Social Sciences and Management Review}

Volume: 04, Issue: 02 "March - April 2021"

ISSN 2582-0176

The result of the analysis in Table 2 shows a significant level $\mathrm{p}<0.05(0.001<0.05)$, rho $=$ 0.391 between Work-Life Balance Satisfaction and Productivity. This denotes that Work-Life Balance Satisfaction relates to Productivity. The null hypothesis was rejected and the alternate hypothesis was accepted.

\section{Discussion of Findings}

Based on the above findings, detailed discussion in line with the hypotheses is given below;

\section{Job Satisfaction and Cohesion}

The bivariate hypotheses between Job Satisfaction and Cohesion reveal a noteworthy relationship between the two variables. The spearman correlation coefficient reveals that the $\mathrm{p}$-value of 0.009 was less than $0.05(\mathrm{p}=0.009<0.05)$ which implies that Job Satisfaction relates significantly with Cohesion. The correlation value $(r)$ is 0.159 . This thus reveals that there is a significant relationship between Job Satisfaction and Cohesion. Thus, enhancing Job Satisfaction will help enhance Cohesion. Thus, the first objective of the study which sought to examine if Job Satisfaction relates to Cohesion was achieved. This finding agrees with that of Krekel, Ward and DeNeve (2019) which contended that employee satisfaction positively correlates with productivity in the organization. Ndulue and Ekechukwu (2016) maintained that employee satisfaction relates positively to cohesion.

\section{Satisfaction and Productivity}

The analysis of hypothesis three reveals a noteworthy relationship between Job Satisfaction and Productivity. The spearman correlation coefficient reveals that the $\mathrm{p}$-value of 0.007 was less than $0.05 \quad(\mathrm{p}=0.007<0.05)$ which implies that Job Satisfaction has a significant relationship with Productivity. Thus the null hypothesis was rejected and the alternate hypothesis was accepted. The result of the correlation coefficient ( $r$ ) is 0.162 . This thus reveals that there is a significant relationship between Job Satisfaction and Productivity. Thus, enhancing Job Satisfaction will help enhance Productivity. Thus the first objective of the study which sought to examine if Job Satisfaction relates to Productivity was achieved. This finding agrees with the works of Agbionu, Ogadi and Agbasi (2013) that job satisfaction has a significant correlation with productivity, and job satisfaction highly increases productivity.

\section{Work-Life Balance Satisfaction and Cohesion}

The bivariate analysis of hypothesis ten shows that Work-Life Balance Satisfaction relates significantly with Cohesion. The $\mathrm{p}$-value of 0.006 which is less than the significant level of $0.05(\mathrm{p}=0.009<0.05)$ indicate that there is a significant relationship between Work-Life Balance Satisfaction and Cohesion. The correlational (r) value of 0.081 implies that there is a high positive correlation between Work-Life Balance Satisfaction and Cohesion. This implies that a change in Work-Life Balance Satisfaction will have a significant impact on Cohesion. If well planned and implemented, Work-Life Balance Satisfaction will help enhance effective Cohesion. These findings is in alignment with that of Garg and Yajurvedi (2016) which 


\section{International Journal of Social Sciences and Management Review}

Volume: 04, Issue: 02 "March - April 2021"

ISSN 2582-0176

observed that work-life balance relates significantly with the performance of corporations and also help enhance job satisfaction.

\section{Work-Life Balance Satisfaction and Productivity}

The analysis of hypothesis twelve showed a significant relationship between Work-Life Balance Satisfaction and Productivity. The p-value of 0.000 which is less than the significant level of 0.05 ( $\mathrm{p}=0.001<0.05)$ indicate that there is a significant relationship between WorkLife Balance Satisfaction and Productivity. The correlational (r) value of 0.391 implies that there is a high positive correlation between Work-Life Balance Satisfaction and Productivity. This implies that a change in Work-Life Balance Satisfaction will have a significant impact on Productivity. If well planned and implemented, Work-Life Balance Satisfaction will help enhance effective Productivity. This finding is in alignment with the work of Yamamoto and Matsuura (2012) that work-life balance has a positive correlation with firm productivity.

\subsection{CONCLUSION AND RECOMMENDATIONS}

The effectiveness of organizations is paramount to the success and wellbeing of the firm. From the analysis and findings, it is observed that job satisfaction has a significant positive correlation with cohesion and productivity. This implies that the productivity and cohesion of the firm can be boost due to job satisfaction of individuals in the establishment. Organizations are social entities whose affairs are piloted by the employees. As such, the job satisfaction of these employees influences their psychological state which thus influences their willingness to put in their best to enhance the effectiveness of the organization. No firm can survive or operate effectively when the employees in the organization are not well satisfied with their job. Enhancing the job satisfaction of these employees in the organization will subsequently result in an increase in the effectiveness of the firm. Also, work-life balance satisfaction relates significantly to the organisational effectiveness of oil and gas firms in Rivers State. The positive significant relationship between work-life balance satisfaction with the measures of organizational effectiveness implies that organizations that are able to enhance the work-life balance satisfaction of their employees are more likely to operate more effectively than organizations that are characterized by a lack of work-life balance satisfaction. Thus creating an atmosphere where employees enjoy work-life balance satisfaction, such will help enhance the total effectiveness of the firm. Conclusively, enhancing the total wellbeing of the employees by ensuring job satisfaction and work-life balance satisfaction of the employees, will help enhance the total effectiveness of the organization.

Based on the findings and conclusions, the following recommendations are provided;

1. Organizations should ensure that workers are well rewarded in order to increase their satisfaction in the workplace and thus boost the effectiveness of the firm.

2. Organizations should ensure that the workplace is more conducive so as to boost the satisfaction of workers which could hence heighten productivity in the firm.

3. Employees in the oil and gas firms should be given stimulating incentive packages in order to enhance their job satisfaction which will thus boost their positive psychological state necessary in enhancing the firms level of effectiveness. 


\section{International Journal of Social Sciences and Management Review}

Volume: 04, Issue: 02 "March - April 2021"

ISSN 2582-0176

4. organizations should create a flexible working environment in which the employees are able to carry out official work even in the convenience, this will enhance their work-life balance satisfaction and thus increase the effectiveness of the organization.

5. The management of the oil and gas firms should give proper attention to enhancing the wellbeing of their employees by providing incentive packages, this will enhance their satisfaction and thus make them to operate diligently to enhance the firms' effectiveness.

\section{REFERENCES}

Adeniyi, O.I. (1995). Staff training and development in Ejiogu, A; Achumba, I. Asika (eds). Reading in Organizational Behaviour in Nigeria, Lagos. Maltho use Press Ltd, P. 159167.

Agbionu, U., Ogadi, P., \& Agbasi, O. (2013). Job satisfaction and organizational effectiveness: A study of public organizations in Anambra state. Humberside Journal ofSocial Science, 2(1), 57-63.

Agho, J.R., Mueller, S.T. \& Price, G.O. (2011), Determinants of job satisfaction of municipal government employees. State Local Government Review, 33(3), 173-84.

Ahmed, Z. \& Shaheen, W. A. (2011). Impact of employee commitment on organizational performance. Arabian journal of business and management review, 1(3), 87 - 98.

Amah, E. \& Ahiauzu, A. (2013). Employee involvement and organizational effectiveness. Journal of Management Development, 32(7), 1 - 27.

Andrew J., D., (1988). The Practice of Supervision, New Delhi; Universal Bookstall.

Andrew, A. (2017). Employees commitment and its impact on organizational performance.

Asian Journal of Economics, Business and Accounting, 5(2), 1- 13.

Anonymous. (2007). Can wellness programs cut medical claims and costs? Contractor's Business Management Report, 8, 1-7.

Argyle, M. (1989). The Social Psychology of Work. 2nd edition. Penguin, Harmonds worth.

Argyle, M. (1989). The Social Psychology of Work. 2nd edition. Penguin, Harmonds worth.

Armstrong, M, (1987) Human Resource Management a case of the emperor's new clothes. Personnel Management, 6, 30-35.

Armstrong, M. (2006). A Handbook of Human resource Management Practice, Tenth Edition, London, Kogan Page Publishing.

Arnett, Z.A., Laverie, U.I. \& McLanes, E.T. (2002), Pay satisfaction and organizational outcomes. Personnel Psychology, 58, 613-640. 


\section{International Journal of Social Sciences and Management Review}

Volume: 04, Issue: 02 "March - April 2021"

ISSN 2582-0176

Balduck, A. L. \& Buelens, M. (2008). A two-level competing values approach to measure nonprofit organizational effectiveness. Working papers of faculty of economics and business administration, Ghent University, Belgium.

Baptiste, R.N. (2008). Tightening the link between employee wellbeing at work and performance a new dimension for HRM. Management Decision, 46(2), 284-309.

Berridge, J., \& Cooper, C. (1994). The employee assistance program: Its role in organizational coping and excellence. Personnel Review, 23(7), 4-20.

Bleischwitz, R. (2010). International economics of resource productivity Relevance, measurement, empirical trends, innovation, resource policies. International Economics and Economic Policy 7(2), 227-244.

Bloom, N, Krestschmer, T \& Van, J. (2006). Work-Life Balance, Management Practices and Productivity. Centre for economic performance. The London School of Economics and Political Science Houghton Street London.

Campbell, J. P. (1977). On the nature of organizational effectiveness. In Goodman, P. S., Pennings, J. M. \& Associates (eds.). New perspectives on organizational effectiveness. San Francisco: Jossey-Bass, 13-55.

Carron, A. V. (1982). Cohesiveness in sport groups: Interpretations and considerations. Journal of Sport Psychology, 4, 123-138.

Carron, A. V., Brawley, L. R., \& Widmeyer, W. N. (1998). The measurement of cohesiveness in sport groups. Advances in Sport and Exercise Psychology Measurement, 213-226.

Carton, R. B. (2004). Measuring organizational performance: an exploratory study. Doctoral dissertation, University of Georgia, Athens, Georgia.

Clark S. C. (2000). Work/family border theory: a new theory of work/family balance. Human Relation, 53, 747-770.

Clarke, M., Koch, L., \& Hill E. (2004), "The work-family interface: Differentiating balance and fit", Family and Consumer Sciences Research Journal, 33(2), 56-61.

Copper, C. L. \& Robertson I. (2001). Wellbeing in organizations a reader for students and practitioners, London, Wiley.

Corbin, C.B., Lindsey, R., Welk, G.J., \& Corbin, W.R. (2002). Concepts of fitness and wellness: A comprehensive lifestyle approach (4th edn.). New York: McGraw Hill.

Cranny, E.R., Smith, I.I. \& Stone, T.U. (2014), Determinants of job satisfaction among police officers. International Research in Modern Sociology, 24(1): 109-16 


\section{International Journal of Social Sciences and Management Review}

Volume: 04, Issue: 02 "March - April 2021”

ISSN 2582-0176

Cropanzano, R., and Wright, T. A. (2001). When a happy worker is really a productive worker: A review and further refinement of the happy-productive worker thesis. Consulting Psychology Journal: Practice \& Research, 53, 182-199.

Currie, D. (2001), Managing Employee Well-Being, Chandos Publishing (Oxford) Limited, Oxford.

Currie, D. (2001), Managing Employee Well-Being, Chandos Publishing (Oxford) Limited, Oxford.

Daft, R. L. (1983) Organization Theory and Design, Minnesota, West Publishing Company.

Darcy, C., McCarthy, A., Hill, J., \& Grady, G. (2012). Work-life balance: One size fits all? An exploratory analysis of the differential effects of career stage. European Management Journal, 30, 111-120.

Davis, K. \& Newtron, J.W. (1985). Human Behavior at work: Organizational Behavior, (7), New York, McGraw Hill.

Ellickson, M.C., \& Logsdon, K. (2002). Determinants of job satisfaction of municipal government employees [Electronic version]. Public Personnel Management, 31(3), 343-358.

Evans, C. R. \& Dion, K. I. (1991). Group cohesiveness and performance: A meta-analysis. Small Group Research, 22, 175-86.

Festinger, L., Schachter, S., \& Back, K. (1950). Social pressures in informal groups: A study of human factors in housing. New York: Harper \& Brothers.

Fleetwood (2007) Why work-life balance now? The International Journal of Human Resource Management. 18(3). 387-400.

Fogaça, N., \& Junior, F., A., C., (2016). Is Happy Worker More Productive. Management Studies, 4(4), 149-160.

Friedlander, F., \& Margulies, N. (1969), Multiple Impacts of Organization Climate and Individual Values System upon Job Satisfaction, Personnel Psychology. 22, 177-183.

Frone, M. R. (2003). Work-family balance. In J. C. Quick \& L. E. Tetrick (Eds.), Handbook of occupational health psychology (pp. 143-162). Washington, DC: American Psychological Association.

Garg, P. \& Yajurvedi, N. (2016). Impact of work-life, balance practices on employees retention and organizational performance. A study on IT industry. Indian journal of applied research, 6(8), $105-108$. 


\section{International Journal of Social Sciences and Management Review}

Volume: 04, Issue: 02 "March - April 2021"

ISSN 2582-0176

George, J.M. \& Jones, G.R. (2008). Understanding and Managing Organizational behavior, Fifth Edition, New Jersey, Pearson/Prentice Hall.

Georgopoulos, B. S. \& Tannenbaum, A. S. (2016). A study of organizational effectiveness. Michigan. University of Michigan.

Goodman, P. S. \& Pennings, J. M. (1980). Critical issues in assessing organizational effectiveness. In Lawler, E. E., Nadler, D. A. \& Cammann, C. (eds.). Organizational assessment: Perspectives on the measurement of organizational behaviour and the quality of work life. New York: Wiley, 185-215

Grant, N., Wardle, J., \& Steptoe, A. (2009) The relationship between life satisfaction and health behaviour: a cross-cultural analysis of young adults, International Journal of Behavioural Medicine, 16, 259-268

Greenberg, R.U. \& Baron, I.F. (2008), Pay enough or don't pay at all. Q. J.Econ., 115: 791810.

Greenhaus, J. H., \& Allen, T, D. (2006). Work-family balance: exploration of a concept. Paper presented at families and work conference, Provo, UT.

Greenhaus, J. H., Collins, K. M., Shaw, J.D. (2003). The relation between work-family balance and quality of life. Journal of Vocational Behavior, 63, 510-53.

Harter, J. K, Schmidt, F. L \& Keyes C (2003) Well-being in the workplace and its relationship to business outcomes: a review of the Gallup studies, In C.L.Keyes and J.Haidt, (eds) Flourishing: the positive person and the good life. Washington, D.C. American Psychological Association, 3(4), 205-224.

Hasan, S., Sentot, I.W., Albert F. I. Othman, A. \& Kaliammah, M.M. (2015), 'Work-Life Balance (WLB) Relationship with Employees Satisfaction: An Evidence from Malaysia Higher Education Institution', International Journal of Science Commerce and Humanities, 3(2), 50-60.

Heraty, N., Morley, M.J. and Cleveland, J.N. (2008), Complexities and challenges in the work-family interface, Journal of Managerial Psychology, 23 (3), 209-214.

Herzberg, F., Mausner, B. \& Snyderman, B.B. (1959). The Motivation to Work. New York: Wiley.

Hill, E. J., Hawkins, A. J., Ferris, M., \& Weitzman, M. (2001). Finding an extra day a week: The positive influence of perceived job flexibility on work and family life balance. Family Relations, 50(1), 49-58.

Hillier, D., Fewell, F., Cann, W., \& Shepard, V. (2005). Wellness at work: Enhancing the quality of our working lives. International Review of Psychiatry, 17(5), 419-431. 


\section{International Journal of Social Sciences and Management Review}

Volume: 04, Issue: 02 "March - April 2021"

ISSN 2582-0176

Hooper, M. (2004). Employee well-being: A hard issue. People Dynamics, 22(3), 8-9.

Hoppock, R. (1935). Job Satisfaction, New York, Harper and Brothers.

Irefin, P. \& Mechanic, M. A. (2014). Effect of employee commitment on organizational performance in Coca Cola Nigeria Limited Maiduguri, Borno State. IOSR Journal of Humanities and Social Science, 19(3), 33 - 41.

Kalliath, T., \& Brough, P. (2008). Work-life balance: A review of the meaning of the balance construct. Journal of Management \& Organization, 14(3), 323-327.

Kamar. O, O., Mariam. A., A., \& Bosede. O., O., (2017). Organizational Commitment and Employee's Job Performance: Evidence from Nigerian Hospitality Industry. International Journal of Innovative Psychology \& Social Development $5(3): 15-22$.

Keith D., \& Newstrom, J. W. (1989). Human Behavior at Work- Organizational Behavior, New York; McGraw-Hill.

Kossek, E. E. \& Lambert, S. J. (2005). Work and life integration: Organizational, cultural and individual perspectives. Mahwah, New Jersey: Erlbaum.

Krekel, C., Ward, G. \& DeNeve, J. (2019). Employee wellbeing, productivity and firm performance. London, centre for economic performance.

Krishantha, P. D. D. M. (2018). Employee wellbeing effectiveness on motivation and organizational performance. International Journal Of Advancements In Research And Technology, 7 (7), $23-40$.

Kushner, R.J., \& Poole, P.P. (1996). Exploring Structure-Effectiveness Relationships in Nonprofit Arts Organizations. Nonprofit Management and Leadership, 7 (2), 119-136.

Lazar, I., Osoian, C., \& Ratiu, P., (2010), The role of work-life balance practices in order to improve organizational performance. European Research Studies, 13, 201-215.

Lease, S. H. (1998). Annual review, 1993-1997: Work attitudes and outcomes. Journal of Vocational Behaviour,. 53(2), 154-183

Locke, E. (1976). The nature and causes of job satisfaction. In M. D. Dunnette (Ed.). Handbook of industrial and organizational psychology, pp.1297-1349). Chicago: Rand McNally.

Manzoor, Q. (2012). Impact of employee's motivation on organizational effectiveness. Business Management and Strategy, 3(1), 1-12.

Martz, W. A. (2008). Evaluating organizational effectiveness. Doctoral dissertation, Western Michigan University, Kalamazoo, Michigan. 


\section{International Journal of Social Sciences and Management Review}

Volume: 04, Issue: 02 "March - April 2021"

ISSN 2582-0176

Martz, W. A. (2008). Evaluating organizational effectiveness. Doctoral dissertation, Western Michigan University, Kalamazoo, Michigan.

Mayerhofer, H., Schmidt, A., Hartmann, L., \& Bendl, R., (2011), Recognizing diversity in managing work life issues of flex patriates. Equality, Diversity and Inclusion: $A n$ International Journal of Management, 4(5), 56-71.

McCann, J. (2004). Organizational effectiveness: Changing concepts for changing effectiveness. Human Resource Planning, 27(1), 204 - 226.

Mello, J.A. (2007). Strategic Human Resource Management. (2nd ed.), India: Cengage South Western.

Mohamud, S. A., Hussein, J. M. \& Mohamud, S. A (2018). The effect of employee commitment on organizational effectiveness: case study of Waaya Aray and Beger electronic companies in Mogadishu - Somalia. International Journal of Current Research, 10(3), $67333-67338$.

Mojahed, S. (2005). A Project Improvement System for Effective Management of Construction Projects, PHD Dissertation. (Unpublished).

Mondy, R.W. (1990). Management and Organization Behavior. Boston, Allyn and Bacon Publishers.

Naithani, P. (2010). Overview of work-life balance discourse and its relevance in current economic scenario. Asian Social Science, 6(6), 148-155.

Nandanwar M.V., Surnis S.V., \& Nandanwar L.M., (2010). "Incentives as tool toward organization success of entrepreneur business: a case study of small scale pharmaceutical manufacturing unit", International Journal of Economics and Business Modelling, 1 (2), 15-20.

Ndulue, T. I., \& Ekechukwu, H. C. (2016). Impact of job satisfaction on employee's performance: A study of Nigeriam Breweries plc Kaduna state branch, Nigeria. Arabian Journal of Business and Management Review, 5(11), 13-23.

Nwagbara, U., \& Akanji, B. O. (2012). The impact of work-life balance on the commitment and motivation of Nigerian women employees. International Journal of Academic Research in Business \& Social Sciences, 2(3), 38-47.

Nwogu, U. J. \& Kaegon, L. E. S (2013). Work-life balance preferences of academic staff of tertiary institutions in Rivers State. Journal of Studies in Education. 1, 147-154.

OECD (2013) OECD Guidelines of Measuring Subjective Well-Being, Paris; OECD Publishing. 


\section{International Journal of Social Sciences and Management Review}

Volume: 04, Issue: 02 "March - April 2021"

ISSN 2582-0176

Ogbo, A. I., Okechukwu, I. \& Ukpere, W. I. (2012). Managing innovations in telecommunication industry in Nigeria. African journal of business management, 6 (25), $7469-7477$.

Oghojafor, B. E. A., Muo, F. I., \& Aduloju, S. A. (2012). Organizational effectiveness: whom and what do we believe? Advances in management and applied economics, 2(4), 81 108.

Oguntimehin, A. (2001) "Teacher Effectiveness: Some practical Strategies for Successful implementation of Universal Basic Education in Nigeria" African Journal of Educational Management, 9(1), 151 - 161.

Olaniyan, D., A., \& Ojo, L., B., (2008). Staff Training and Development: A Vital Tool for Organizational Effectiveness. European Journal of Scientific Research. 24(3), 326331.

Oswald, A. J., Proto, E. \& Sgroi, D. (2014) "Happiness and Productivity", University of Warwick mimeo. Forthcoming in the Journal of Labor Economics.

Parks, K., \& Steelman, L. (2008). Organizational Wellness: A Meta-Analysis. Journal of Occupational Health Psychology, 13(1), 58-68.

Quick, J. D., Henley, A. B., \& Quick, J. C. (2004). The balancing act: At work and at home. Organizational Dynamics, 33(4), 426-438.

Rao, P. S., (2000). Essentials of Human Resource Management and industrial relations, Mumbai, India, Himalaya publishing House.

Reilly, C.R. (1991). Organizational Behavior. Annual Review of Psychology, 4. 427- 458.

Rosh, L., Offermann, L. R., \& Van Diest, R. (2012). Too close for comfort? Distinguishing between team intimacy and team cohesion. Human Resource Management Review, 22(2), 116-127.

Russell, J.E.A. (2008). Promoting Subjective Well-Being at Work. Journal of Career Assessment, 16(1), 117-131.

Ryan, M. R., \& Deci, L. E., (2000). Self-Determination Theory and the Facilitation of Intrinsic Motivation, Social Development, and Well-Being, American Psychologis.t

Sakthivel, D. \& Jayakrishnan, J. (2012). Work Life Balance and Organizational Commitment for Nurses. Asian Journal of Business and Management Sciences, 2 (5), 01-06.

Sakthivel,R \& Kamalanabhan (2011). Work life balance reflections on employee satisfaction. Serbian Journal of Management 6 (1), 85-96. 


\section{International Journal of Social Sciences and Management Review}

Volume: 04, Issue: 02 "March - April 2021"

ISSN 2582-0176

Salanova, A., \& Kirmanen, S., (2010). Employee Satisfaction and Work Motivation. Research in Prisma Mikkeli

Scholarios, D., \& Marks, A. (2006). Worklife balance and the software worker. Human Resource Management Journal, 14(2), 54-74.

Serxner, S. A.; Gold, D. B. \& Bultman, K. K. 2001. The Impact of Behavioral Health Risks on Worker Absenteeism. Journal of Occupational \& Environmental Medicine. 43(4), 347-354.

Shaw, M. E. (1981). Group Dynamics: The Psychology of Small Group Behavior (3rd ed.). Montreal, Quebec: McGraw-Hill.

Shiva M.S.A. \& Suar D. (2010). Leadership, LMX, Commitment and NGO Effectiveness : Transformational Leadership, Leader-Member Exchange, Organizational Commitment, Organizational Effectiveness and Programme Outcomes in NonGovernmental organizations. International Journal of Rural Management, 6(1), 117150.

Simatwa, E. M. W. (2011). Job Satisfaction and Dissatisfaction among Teachers in Kenya. Kenya Journal of Education Planning Economics and Management. 3 (3), 114-123.

Simatwa, E. M. W. (2011). Job Satisfaction and Dissatisfaction among Teachers in Kenya. Kenya Journal of Education Planning Economics and Management. 3 (3), 114-123.

Singh, J., K., and Jain, M., (2013). A study of employees' job satisfaction and its impact on their performance. Journal of Indian Research, 1(4), 105-111.

Singh, Y. P. (2013). Quality of work life and its impact on organizational performance. Asia Pacific Journal of Management \& Entrepreneurship Research, 2, 240-246.

Sinikka, V. \& Kaija, T. (2006). HRM, company performance and employee wellbeing. Management review, 17(3), $241-255$.

Smith, F.J., Kendall, Z.W. \& Hulin, E.M. (2007), Job Satisfaction of Professional and Paraprofessional Library Staff at Chapel Hill, North Carolina. University of North Carolina at Chapel Hill.

Smith, K., T., (2010). Work-life balance perspectives of marketing professionals in generation Y. Services Marketing Quarterly, 31, 434-447.

Statt, D. (2004). The Routledge Dictionary of Business Management, Third edition, Detroit, Routledge Publishing.

Syverson, C., (2011). What Determines Productivity? Journal of Economic Literature 49(2), 326-365. 


\section{International Journal of Social Sciences and Management Review}

Volume: 04, Issue: 02 "March - April 2021"

ISSN 2582-0176

Szücs, S., Drobnic, S., Den Dulk, L., Verwiebe, R. (2011): Quality of life and satisfaction with the work-life balance, in: Bäck-Wiklund, M. et al. (Eds.): Quality of Life and Work in Europe, New York, pp. 95-117

Vidal, M., E., S., Valle, R., S., \& Aragón, B., M., I ., (2007). Antecedents of repatriates’ job satisfaction and its influence on turnover intentions: Evidence from Spanish repatriated managers. J. Bus. Res., 60, 1272-1281.

Vroom, V.H. (1964). Work and motivation, John Wiley and Sons, New York, p.99.

Wiredu, G.K. (1989), Productivity in the Ghanaian Civil Service, MBA Thesis, (Unpublished)

Yadav, P., \& Marwah, C., (2015). The Concept of Productivity. International Journal of Engineering and Technical Research, 3 (5), 41-62.

Yadav, P., \& Marwah, C., (2015). The Concept of Productivity. International Journal of Engineering and Technical Research, 3 (5), 41-62.

Yamamoto, I., \& Matsuura, T. (2012). Effect of work-life balance practices on firm productivity: Evidence from Japanese firm level panel data. The research institute of economy, trade and industry discussion paper.

Yamane, T. (1967). Statistics: An introductory analysis, $2^{\text {nd }}$ ed. New York: Harper and Row.

Yuchtman, Ephraim, \& Stanley E, Seashore. A System Resource Approach to Organizational Effectiveness, American Sociological Review, 32, 891-903.

Zheng W., Yang B., \& McLean G. (2010). Linking organizational culture, structure, strategy, and organizational effectiveness: Mediating role of knowledge management. Journal of Business Research, 63(7),763-771. 